\title{
Anastasiia Yezhova \\ RELOCATION OF THE CREATIVE CLASS TO THE SMALL CITIES DUE TO COVID-19: DISCUSSION ON A NEW CITY MARKETING NICHE
}

Anastasiia Yezhova, PhD student, University of Public Service, Doctoral School of Public Administration, yezhova.nastya@gmail.com

Relocation to small cities is becoming more and more widespread. Due to the Covid-19 pandemic, people are trying to escape from perceived danger and as an alternative, they are considering short-term or long-term relocation to smaller cities or towns.

Purpose: in this paper, the author gathers the experiences of people constituting a creative class, who relocated from capitals and metropolises to small cities during the Covid-19 pandemic and before, recording and defining certain motives for their move.

Methodology: both primary and secondary sources were used for content analysis. As a primary source, ten in-depth interviews were conducted, whereas secondary sources include blogs and online published interviews. This article investigates three questions about relocation: 1. Why do people move from bigger cities to small ones? 2. What does the creative class pay attention to before choosing a settlement for permanent or temporary relocation? 3. How can the administration of the small cities reinforce their attractiveness for potential residents and tourists from the creative class?

KEYWORDS:

city marketing, Covid-19, creative class, local government, migration, pandemic 


\section{INTRODUCTION}

Relocation to small cities is becoming more and more widespread. Before the Covid-19 pandemic, life in big cities was expensive, but more importantly, it has now become potentially dangerous with overcrowded public transport, queues in the supermarkets, narrow streets, etc. Inhabitants of cities have begun seeking to escape from perceived danger and as an alternative, they are considering short-term or long-term relocation to smaller cities or towns, which have an adequate infrastructure, fresh air and lower prices. Working from home, (generally known as "home office") became a catalyst for this trend as lots of office workers switched to remote working.

Meanwhile, several countries are introducing a new type of visa - a visa for remote work. This type of employment has different names depending on the state: freelance employment, self-employed, virtual working, global citizen visa, etc. The variety of titles does not change the concept - countries are striving to attract members of the affluent creative class to live and conduct economic activity in their territories because people mostly spend money where they live.

This article addresses three questions about relocation: 1 . Why do people move from bigger cities to small ones? 2. What does the creative class pay attention to before choosing a settlement for permanent or temporary relocation? 3. How can the governments of small cities reinforce their attractiveness for potential residents and tourists from the creative class?

In this paper, the author gathers the experiences of people who relocated from cities with over one million residents to small cities (less than 500 thousand inhabitants) and explores the reasons and motives for their relocation. The research is based on in-depth interviews with migrants, both internal and external, and online published interviews and blogs. From the responses of the informants, it is possible to trace how exactly such people describe their motivation to move. It should be noted, then, that both primary and secondary sources were used for content analysis. In this research, primary sources means in-depth semi-structured interviews, whereas secondary sources include blogs, online published interviews and columns. In total, ten in-depth interviews were conducted by the researcher via Zoom, Skype or with the help of the Instagram and Facebook social networks. The interviewees were personal contacts of the researcher, whose age varied from 23 to 41 years old. As regards secondary sources, fourteen blogs and online magazine interviews were analysed. The occupation of the respondents include photographer, doctor, owners of coworking space, frontend developer, marketing consultant, editor, graphic designer, software development manager and an owner of an internet shop. The places of residence of the respondents were Kyiv, Lviv, Sumy, Mukachevo, Bila Tserkva, Warka, Moscow and Minsk.

Before conducting the personal interviews, the main categories of expected reasons for the changing city were identified by the researcher based on the review of the literature search presented below. These included cost of living, rental prices, entertainment, ecology, safety, public transport and pace of life. In the process of carrying out the interviews, other 
topics such as climate, logistics (transport connection with other cities and countries), inner distances, coworking spaces, local intimacy and networking were added as they arose. The "Ecology" block was enriched with the issue of the availability of "farmer's food" which was often mentioned by the respondents.

\section{LITERATURE REVIEW}

The United Nations classification of the size of the cities was used in this paper. According to this taxonomy, megacities number more than 10 million residents, large cities have 5 to 10 million inhabitants, medium-sized cities have 1 to 5 million citizens while cities of between 500,000 and 1 million inhabitants were not assigned a specific category in the World Migration Report (2015), and cities with fewer than 500,000 residents were called small. This research will focus on cities in the last category.

In 2017 the German company Zipjet shared the results of a study that ranked cities from those with the lowest to the highest stress levels. ${ }^{1}$ To identify which cities' residents are most or least at risk of being under stress, the researchers outlined several criteria, dividing them into four groups: "City", "Environment", "Finance" and "People". The first group included the following criteria: population density, green areas, passenger traffic (public transport), road traffic (traffic jams, road quality), safety in the streets and number of hours of sunshine. The environmental category involves levels of air and noise pollution and the city's illumination. The "Finance" group took into account the unemployment level, debt per capita, social security (amount of social payments, insurance), and the average cost of living per family per month. The last group "People" included criteria of mental health (number of suicides; the number of psychologists), physical health (percentage of GDP allocated to health care), gender equality and ethnic equality.

The criteria for relocation defined in the process of this research partially correspond to the ones developed by Zipjet. Some criteria, such as gender and ethnic equality were mentioned only once, however, given that all the respondents and authors of the blogs are representatives of the Caucasian race and Slavic ethnicity (Ukrainians, Russians and Belarusians) and they moved to the cities where this was the prevailing ethnicity. This could be considered to be a limitation of this study.

While developing the interview blocks, the author also referred to some new trends in city development, which were described on the main city portal of the Finnish capital "My Helsinki". ${ }^{2}$ These were influenced by recent world events, and, logically, they mostly correspond to the concept of a slow life (slow living and the green economy) as a counterbalance to stressful and hurried big city life. These included:

Julia Toman, 'How does the stress level change in cities?'

MyHelsinki, 'Work life worth living', MyHelsinki, 16 December 16. 
1. Safety (hygiene, security)

2. Work and leisure balance (the blurring of the boundaries between work and leisure)

3. Space and silence

4. Responsible tourism (includes the impact of our actions on the local population)

5. Digitalisation

A considerable academic literature has developed on the topics of migration and the reasons for it. Many years of empirical research have been devoted to these areas using large amounts of statistical information, surveys, as well as qualitative research, including in-depth interviews (Michaela Benson, William A. V. Clark, William Lisowski, Regan Maas, Karen O’Reilly, Alicja Bobek, Yong Chen, Stuart S Rosenthal, etc.). However, Vinogradskaya has rightly pointed out that nowadays the majority of research on relocation is devoted to the topic of migration from villages and towns to big cities. ${ }^{3}$ Meanwhile, studies about migration in the opposite direction, the narrow category of migration from big cities to smaller ones, are much less common. Furthermore, research into this type of migration usually concerns the retirement-aged population, which tends to move to or spend long period of time in rural areas and smaller cities while paying almost no attention to the employment opportunities there. ${ }^{4}$ It is also worth mentioning the processes of suburbanisation that are widely covered in the Central European literature. This tendency has been typical for postsocialist countries since the 1960s, triggered by industrial decentralisation and housing problems. ${ }^{5}$ The reasons for suburbanisation in the $20^{\text {th }}$ century included the opportunity to farm the household land, but then it was vital not in the sense of a healthy lifestyle like nowadays, but for survival in times of food scarcity.

\section{CREATIVE CLASS THEORY}

It is often mistakenly assumed that cities predominately increase their revenue due to outsider investors or tourists, but in reality, the core contributing participants are their residents. Therefore, the city budget is maintained by the taxes and investments (e.g. into

O Y Vinogradskaya, 'Why and from what townspeople move to the village: phenomenology and practice', Russian Peasant Studies 4, no 3 (2019), 140-155.

4 John Cromartie and Peter Nelson, 'Baby Boom Migration and Its Impact on Rural America', United States Department of Agriculture, Economic Research Report no 79 (2009); Jiaying Lyu, Huan Huang and Zhenxing Mao, 'Middle-aged and older adults' preferences for long-stay tourism in rural China', Journal of Destination Marketing \& Management 19 (2021); Allan M Williams et al., 'Tourism and international retirement migration: New forms of an old relationship in southern Europe,' Tourism Geographies 2, no 1 (2000), 28-49.

5 Jaroslav Biolek et al., 'Interrelated aspects of residential suburbanization and collective quality of life: A case study in Czech suburbs', Acta Geographica Slovenica 57, no 1 (2017); Judit Timár, 'The main features of suburbanization in the Great Hungarian Plain', Landscape and Urban Planning 22, no 2-4 (1992), $177-$ 187; Petr Hlaváček, Miroslav Kopáček and Lucie Horáčková, 'Impact of Suburbanisation on Sustainable Development of Settlements in Suburban Spaces: Smart and New Solutions', Sustainability 11, no 24 (2019), 71-82. 
real estate) from the local population. Keeping in mind the prevailing population trends, ${ }^{6}$ the municipal budget of small cities will shrink concurrently with the population decrease. Therefore, cities should conduct strategic planning with a major focus on retaining the local population and attracting new inhabitants. This statement can be reinforced by the Creative Class theory developed by Richard Florida.

Not long ago urban research focused on institutions as the key object of their analysis. More recently, however, skills have become the core element in societal urban research. ${ }^{7}$ The nature of the economy is changing - the industrial revolution is being replaced by the skills revolution, where the success and development of places are based upon knowledge, innovation and skills.

In studies where the variable is considered to be the creative class, the correlation between it and economic development is positive in the countries of the Western world. ${ }^{8}$ Although similar research has not been conducted in the countries of the post-Soviet region, the influence of the creative class on technological development is significant and beyond suspicion.

The notion of "class" was introduced by Karl Marx and refers to a set of people who have common interests and who tend to think, feel and behave similarly (the term "lifestyle" can be used in this regard). These similarities are fundamentally determined by the types of work that provide them with a means of sustenance. Marx's theory also explains the reasons for social disparity by the existence of class stratification. Despite the fact that some contemporary sociologists have announced the death of Marx's theory and consider its usage in research as "bad manners" (mauvais ton), the founder of the creative class theory Richard Florida refers to exactly such a notion of class. ${ }^{9}$

Originally from the United States of America, currently living in Canada, the economist and sociologist Richard Florida, Professor of the Rotman School of Management at the University of Toronto, wrote the book The Rise of the Creative Class, which was published in 2002. In this monograph, Florida puts forward a hypothesis about the formation of a new social stratum in modern megacities, which not only positively

June J H Lee et al., World Migration Report 2015: Migrants and Cities: New Partnerships to Manage Mobility (Geneva: International Organization for Migration, 2015).

7 Charlotta Mellander and Richard Florida, 'The Rise of Skills: Human Capital, the Creative Class, and Regional Development', in Handbook of Regional Science, ed. by Manfred M Fischer and Peter Nijkamp (BerlinHeidelberg: Springer, 2019).

8 Ted D Naylor and Richard Florida, 'The Rise of the Creative Class: And How It's Transforming Work, Leisure, Community and Everyday Life', Canadian Public Policy/Analyse de Politiques 29, no 3 (2003), 378; Gerard Marlet and Clemens van Woerkens, 'The Dutch Creative Class and How it Fosters Urban Employment Growth', Urban Studies 44, no 13 (2007), 2605-2626; Charlotta Mellander and Richard Florida, 'The Creative Class or Human Capital? Explaining Regional Development in Sweden', Working Paper Series in Economics and Institutions of Innovation, 2007; Mellander and Florida, 'The Rise of Skills: Human Capital, the Creative Class, and Regional Development'; Joachim Möller and Annie Tubadji, 'The Creative Class, Bohemians and Local Labor Market Performance', Jahrbücher für Nationalökonomie und Statistik 229, no 2-3 (2009).

9 Елена Александрова, 'В гостях у Флориды: размышления над книгой «Креативный класс: люди, которые меняют будущее», Экономическая социология 9, по 1 (2008), 132-138. 
affects the growth of the urban economy and the quality of life, but also represents a prototype of the personality of the future, as well as the main factor of future social progress.

According to Florida, the core of the creative class is primarily composed of people employed in science, technology, architecture, design, education, art, music and entertainment, i.e. people whose work produces new ideas, technology and products. In addition to these professions, the creative class also includes specialists who have sophisticated, independent and non-standard ways of thinking although a high level of education is not an integral part of the creative professional. For example, a musician who only has a school certificate but who is involved in the music industry also constitutes a part of the creative class. Membership in the class is conferred not by qualification but by pursuing a creative profession.

Richard Florida finds the solution to the riddle of the chicken and the egg (economic development and creative people) on the side of people. He assumes that the presence of creative people in a settlement makes it flourish and develop. ${ }^{10}$

In other words, companies and productions will be located in places where there is a high concentration of talent. The theory of endogenous growth supports this argument, stating that the presence of large numbers of high-skilled and creative people leads to innovation and knowledge spillovers (exchange of useful information, sometimes involuntary leakage). ${ }^{11}$ These positive effects, in turn, are caused by inhabitants' close interaction, the high probability of their paths crossing, and low travel costs. ${ }^{12}$ However, Paul Krugman harshly criticises this hypothesis due to the lack of firm statistical evidence to support it. ${ }^{13}$

At the same time, cities have to compete to attract the creative class and a high-skilled labour force by providing a satisfying and suitable living environment. By this, Florida means not only high-quality infrastructure (which is of course extremely important) but also the tolerance level of the members of the community. By tolerance, we mean the acceptance of different ideas, backgrounds, behavioural patterns or appearances by society. It means that society does not judge or exclude a person on the basis of their beliefs, nationality or sexual orientation, etc. Richard Florida investigates the effect of tolerance towards gay people in his research, which turns out to have a positive correlation with the level of technological development and economic prosperity of the cities - the more tolerant a society is, the more prosperous an economy it has.

Both human capital and creative class positively influence the economic development of a settlement. Consequently, cities should focus on attracting talented and skilled people,

Mellander and Florida, 'The Rise of Skills: Human Capital, the Creative Class, and Regional Development'. Michel Dumont and Wim Meeusen, 'Knowledge spillovers through R\&D cooperation', 2000.

Edward L Glaeser, 'Cities and Ethics: An Essay for Jane Jacobs', Journal of Urban Affairs 22, no 4 (2000), 473493.

13 David B Audretsch, Erik E. Lehmann and Joshua Hinger, 'From Knowledge to Innovation: The Role of Knowledge Spillover Entrepreneurship', in Routledge Handbook of the Economics of Knowledge, ed. by Cristiano Antonelli and Albert Link (London: Routledge, 2014). 
who can be absorbed into the ranks of residents. Cities also have to meet some other criteria to be appealing in the eyes of potential citizens. Tolerance was mentioned, which is one of the main criteria for moving. This is especially true for skilled migrants from other countries. Knowing that the local community is xenophobic not only dissuades individuals from moving to a city but also becomes a barrier for international companies wishing to open offices or factories. Secondly, cities should be rich in the aspect of culture. The creative class is very choosy when it comes to their physical environment, the variety of leisure activities available and mobility. A high number of coffee shops, bars, restaurants, green urban spaces and comfortable public transport are important components of the "ideal" city for the creative class.

\section{REASONS FOR RELOCATION}

Raphael Bob-Waksberg wrote an engrossing story Move Across the Country, where he describes the process of escape from "Sadness" to another city: "Move across the country and watch the short yellow lines shoot past you down the pavement. ... Settle somewhere fertile, plant a new you and watch you blossom." ${ }^{14}$ These lines perfectly describe the anxious state of mind of a person who has moved to a new destination in a search for a better life or to flee from undesirable circumstances.

The Covid-19 pandemic has raised many new questions concerning choice of a place to live. Is it safe enough in a sense of security and hygiene? Do we have the space to find a balance between work and leisure? Are there places to find silence at moments when we need it? Quite apart from their admittedly high housing prices and rising inequality, cities with a million population can offer thousands of square meters of office spaces, a plethora of entertainment opportunities and non-stop public transport. It may be asked, however, whether this still matters as much as before Covid-19? People have arrived at the point where the "15-minutes city concept" of the decentralised city looks much more appealing than a two-hour commute. At the same time, closeness to nature is increasingly appearing in the list of requirements while choosing a place of residence.

This all brings us to the rise of the small cities that can combine both peace and calm with mild hustle and bustle. Metropolises usually attract people because of the career opportunities they offer, bearing in mind that large numbers of international companies locate their headquarters there. The recent switch to remote work, however, allows employees to visit office spaces only a couple of times a week or not to visit them at all. This company strategy is called "Remote-first", which "makes working remotely the primary option for most or all employees". ${ }^{15}$ Not to mention freelance workers, who help companies to respond quickly to the changes in the volatile business environment, by working

\footnotetext{
14 Raphael Bob-Waksberg, Someone Who Will Love You in All Your Damaged Glory (New York: Alfred A Knopf, 2019).

15 VMware, 'What is Remote-first?', s. a.
} 
under commercial contracts instead of conventional fixed hours contracts from any part of the world with flexible working hours. This presents a unique opportunity for small cities to attract talent, and therefore they should develop their communication capacities and reconsider the focus of their promotion activities (or create everything from scratch in case they are absent).

This does not mean that the creative class, which mostly dwells in big cities, will immediately move to the provinces. They may also consider the option of "slow tourism" meaning that remote workers and freelancers can spend more than a week in one place, bringing economic benefits to the settlement. Consequently, cities and towns need to make efforts to end up on the itineraries of creative professionals. Moreover, there is always a chance that a person might end up settling in the place without the prior intention of doing so.

What does the creative class consider before choosing the destination for short-term or long-term relocation? Eleven main reasons emerged from the interviews conducted for the research described here. In each respondent's case, the combination of pull-in motives is unique and prioritised differently. Below each motive, several quotations from the interviews are presented, which can reveal more precisely the vision of what lies behind their choice.

1. Climate. This was a significant factor especially in Northern countries, where winter lasts for more than three months. People are looking for more sunny days due to suffering from seasonal affective disorder or even to save on heating expenditure. Nevertheless, Global Warming has created an opposite trend where in summer people flee from the heat to the North.

Having moved to Kaliningrad, we found a better climate, a better ecological situation, became calmer and spend more time at the sea and in the fresh air (A, AstrakhanKaliningrad, editor). ${ }^{16}$

2. Lower prices. The internet website Numbeo allows users to compare the cost of living in different countries and cities (Figure 1). Receiving the same wage in different cities may be set against different quality of living conditions. While in one city 250 euros is only enough to rent a room, in another this may be sufficient for a whole three-room apartment.

\begin{tabular}{|c|c|c|c|}
\hline Rent Per Month & Kiev (Kyiv) & Sumy & \\
\hline Apartment ( 1 bedroom) in City Centre & $16,026.80 z$ & $4,562.50 z$ & $-71.53 \%$ \\
\hline Apartment ( 1 bedroom) Outside of Centre & $9,335.01 z$ & $3,312.50 z$ & $-64.52 \%$ \\
\hline Apartment ( 3 bedroom) in City Centre & $29,421.37 z$ & $6,437.50 z$ & $-78.12 \%$ \\
\hline Apartment ( 3 bedroom) Outside of Centre & $16,315.14 z$ & $5,142.86 z$ & $-68.48 \%$ \\
\hline
\end{tabular}

Figure 1 Comparison of the rental process in the Ukrainian cities Kyiv and Sumy, 2021 Source: numbeo.com

16 Александр Воробьев, 'Все, что вы хотели знать о релокации по России: направления, стоимость и личные истории', Perito Burrito, 20 January 2021. 
In Warsaw, if you want to find a good studio apartment, you need to spend a minimum of 2000 zloty (430 euros). In Sumy, you can find a one-room flat for 3000 hryvnias (90 euros). ( N, Warsaw-Sumy, 23 years old, software development manager).

3. Quality of environment (farm produce, air, light and noise pollution). In big cities, it is difficult to organise the procurement of fresh food directly from the farmer. Usually, bigger players organise logistics and distribution. In towns weekend vending can still be found, when farmers pay for a stall in the marketplace only for Saturday and Sunday.

4. Closeness to nature, landscape, seaside. Some decide to move precisely because of the lack of greenery in the city, and, in turn, the remoteness of or lack of accessibility to nature (which is over a one-hour trip away). Also, some respondents were haunted by the desire to live by the sea or in the mountains, which is also closely related to the quality of the air and the environment.

At any moment I can reach the forest in 10 minutes ( $D, 31$ years old, doctor).

5. Logistics. There was no consensus on this issue among the respondents since for many it is important for a city to have acceptable transport connections with the outside world (including an airport), and to be relatively close to the capital. For others, even five hours by bus to the destination is not an obstacle.

6. Leisure and sports facilities. Interestingly, most of the interviewees did not regard the lack of a wide range of entertainment a reason not to move to a city. The main idea of many was that they are quite capable of organising their own leisure time if necessary. They also claimed that to maintain good physical shape, a pair of sneakers is enough. However, the presence of theatres, museums, sports facilities or shopping centres was naturally seen as a plus for the settlement.

This week I have everything planned: on Saturday I go to a master class in calligraphy, on Sunday to a business game. [...] People initiate and organize their own leisure (R, KyivSumy, 26 years old, graphic designer).

You can establish something new if you cannot find it (type of entertainment) in your city. You just need to make up your mind (N, Warsaw-Sumy, 23 years old, software development manager).

7. Public transport quality. Small towns do not need many units of public transport or can even exist without it since it is possible to reach any part of the city within half an hour on foot or by bicycle. In small cities, however, public transport is an important component. Also, the respondents repeatedly raised the possibilities of car and bicycle sharing.

We do not need public transport in Warka, everything can be reached on foot or by bike. Moreover, great cycling infrastructure allows you to do that with pleasure (K, WarsawWarka, 41 years old, photographer). 
8. Coworking space. Coffee shops can also serve as a place of work in the absence of coworking spaces, and for some of the interviewees it turned out to be not at all necessary since they prefer to work from home and leave a visit to a cafe for friendly conversations or other events.

9. The pace of life. Absolutely all the respondents agreed on this point, believing that the hectic pace of life in large cities increases stress levels, as well as worsening the quality of interpersonal communication and the ability to maintain relationships. Intimacy is what makes small towns attractive to many.

In a big city, there are a lot of people, and when you move in the stream you do not feel free (D, 31 years old, doctor).

10. Distances and traffic jams. Short distances save time, allowing for much more free time, which creates a better balance between work and rest. Respondents appreciated not having to spend money on a taxi at night. If the city is safe enough, then they can get anywhere on foot.

I feel sorry for the time it took me to get somewhere (in Kyiv). And it doesn't matter if you have personal transport or not. All the same, you will be stuck in traffic jams (D, 31 years old, doctor).

In Sumy, I can control my pace of life. In Kyiv, because of the distance and transport, it was impossible (R, Kyiv-Sumy, 26 years old, graphic designer).

11. Networking and local intimacy. This point overlaps with the one about the pace of life. People strive for high quality interpersonal communication and long-term relationships, which provide a sense of integration and involvement. In a small town, it is much easier to achieve this because fewer events and fewer participants make them more likely to meet again. In turn, everyone knows each other, albeit indirectly, which ensures the absence of discomfort and creates a kind of "homely atmosphere". Moreover, the "Six Degrees of Separation" theory is reduced to two or three.

Now I strive for quality communication, not quantitative ( $R$, Kyiv-Sumy, 26 years old, graphic designer).

In small cities, there is sometimes even more quality entertainment than in large ones: intimate celebrations or events. People get closer there and communicate. [...] I have a feeling that the purpose of events in large cities is simply to make money $(D, 31$ years old, doctor).

\section{HOW CAN THE ATTRACTIVENESS OF A SMALL CITY FOR RELOCATION BE REINFORCED?}

After analysing the reasons for relocation given by the respondents and what they pay attention to when choosing a settlement, the author outlined the following points when developing a strategy to attract the creative class for relocation and slow tourism. 
1. Urban planning in conformity with the international standards of safety. ${ }^{17}$ The shining example of the latest proposed practices in transportation and street design in response to the Covid-19 pandemic is a document entitled Streets for Pandemic Response \& Recovery developed by the National Association of City Transportation Officials in the framework of its programme called Global Designing Cities Initiative. Specific designs for various places like markets, school areas or dining streets can be found there governed by principles of safety, public health and support for local business.

2. Google Maps add professional pictures of the city's landmarks to the place. Google Photos check can be found among tips on move and relocation. These common tips also include searching for local Facebook groups and Instagram locations. ${ }^{18}$

3. Creation and development of participatory budgeting. This allows citizens to have real power in the allocation of the municipal budget through their projects and voting procedures. Moreover, it allows the public administration to see the current demands of society through the thematic scope of the applied projects.

4. Support local farming by giving them space for trade in the city.

5. Development of infrastructure in the natural surroundings on the territory of the city (usually in the outskirts) to save the environment while allowing people to enjoy time outside. This may include wooden pathways, cycle lanes, specialised places for bonfires or barbecues, pavilions providing shelter from the rain or sun, etc.

6. Investing in the green economy (bicycles sharing system and cycling infrastructure, e-transport, development of the charging station network).

\section{CONCLUSIONS}

The local councils of small cities should consider short-term and long-term relocation trends as an opportunity for attracting new inhabitants and tourists to their settlement, especially if their budget previously depended on income from tourism. The main task of the local government is to create safe conditions for residents because of the new challenges that the pandemic has brought and to continuously carry out research into the needs of the population.

Respondents to the survey carried out for this study, who moved to small towns before the pandemic, gave as reasons for relocation calmness, a healthy environment, low cost of living, short distances, intimate communication and ease of maintenance. During the pandemic, the list of reasons expanded to include safety, a smaller population, and, consequently, the absence of crowds, a low need for using public transport, the ability to quickly move around the city by bicycle, and the absence of traffic jams. The catalyst for relocation during the pandemic for many was the transition to remote working. Wages

17 National Association of City Transportation Officials, 'Streets for Pandemic: Response \& Recovery', News Release, 25 June 2020.

18 Hannah Wise, 'How to Move During the Coronavirus', The New York Times, 24 July 2020. 
have remained at the same level but in a small town they can afford more for the same money.

As noted in the study by Richard Florida, the creative class is, for the most part, quite demanding of urban conditions and the opportunities in it. According to our study, some pay attention to the climatic conditions and the number of sunny days in the city, while for others urban landscapes, the sea or mountains are important. Undoubtedly, the creative class considers the ecology of the area, and during the interviews, farm products and the possibility of purchasing them directly from farmers were mentioned more than once. Closeness to nature is just as important for those who move; one of the problems of their life in a big city was that it took at least an hour to travel to the forest or countryside. One controversial issue turned out to be the topic of logistics, or, in other words, the transport connection of the city with big cities, countries or the capital. For some, this is paramount (some even demanding the availability of an airport), while for the rest it does not matter, because even the prospect of spending five hours on the road to their destination does not scare them. The quality of public transport was a fairly common criterion among the respondents, as well as the availability of bicycle or car rental/sharing services in the city. It was a surprise for the researcher that the creative class does not consider small cities boring in terms of activities and the availability of entertainment. Most believe that people can organise their leisure time for themselves if they lack something in the city. Social networking sites make it easy to gather like-minded people in the area. Naturally, not everyone has a high level of initiative, so the latter cannot be generalised for everyone.

Among the main recommendations for the administration of small towns for how to attract a creative class for short or long-term visits, it is worth highlighting urban planning within the framework of new international safety standards; creating or maintaining a participatory budget, thanks to which residents receive financial support for their initiatives and for developing their networking; supporting farming by providing farmers with points of sale and interaction with urban residents; development of hiking and cycling infrastructure on the outskirts of the city, where people can interact with natural features such as forests, rivers, mountains, etc. and investing in the green economy. 


\section{REFERENCES}

1. Александрова, Елена, 'В гостях у Флориды: размышления над книгой «Креативный класс: люди, которые меняют будущее». Экономическая социология 9, no 1 (2008), 132-138. Online: https://doi.org/10.17323/1726-3247-2008-1-132-138

2. Audretsch, David B, Erik E Lehmann and Joshua Hinger, 'From Knowledge to Innovation: The Role of Knowledge Spillover Entrepreneurship', in Routledge Handbook of the Economics of Knowledge, ed. by Cristiano Antonelli and Albert Link. London: Routledge, 2014. Online: https://doi.org/10.4324/9780203082324

3. Biolek, Jaroslav, Ivan Andráško, Jiří Malý and Pavlína Zrůstová, 'Interrelated aspects of residential suburbanization and collective quality of life: A case study in Czech suburbs'. Acta Geographica Slovenica 57, no 1 (2017). Online: https://doi.org/10.3986/AGS.909

4. Bob-Waksberg, Raphael, Someone Who Will Love You in All Your Damaged Glory. New York: Alfred A Knopf, 2019.

5. Воробьев, Александр, 'Все, что вы хотели знать о релокации по России: направления, стоимость и личные истории'. Perito Burrito, 20 January 2021. Online: https://perito-burrito.com/posts/best-relocation-destinations

6. Cromartie, John and Peter Nelson, 'Baby Boom Migration and Its Impact on Rural America'. United States Department of Agriculture, Economic Research Report no 79 (2009). Online: www.ers.usda.gov/webdocs/publications/46218/9346_err79_1_. pdf? $=41056$

7. Dumont, Michel and Wim Meeusen, 'Knowledge spillovers through R\&D cooperation', 2000. Online: www.oecd.org/sti/inno/2093436.pdf

8. Glaeser, Edward L, 'Cities and Ethics: An Essay for Jane Jacobs'. Journal of Urban Affairs 22, no 4 (2000), 473-493. Online: https://doi.org/10.1111/0735-2166.00068

9. Hlaváček, Petr, Miroslav Kopáček and Lucie Horáčková, 'Impact of Suburbanisation on Sustainable Development of Settlements in Suburban Spaces: Smart and New Solutions'. Sustainability 11, no 24 (2019), 71-82. Online: https://doi.org/10.3390/su11247182

10. Lee, June J H, Lorenzo Guadagno, Ann-Christin Wagner, Sansae Cho and Yuka Takehana, World Migration Report 2015: Migrants and Cities: New Partnerships to Manage Mobility. Geneva: International Organization for Migration, 2015. Online: https://publications.iom.int/system/files/pdf/wmr2015_en.pdf

11. Lyu, Jiaying, Huan Huang and Zhenxing Mao, 'Middle-aged and older adults' preferences for long-stay tourism in rural China'. Journal of Destination Marketing \& Management 19 (2021). Online: https://doi.org/10.1016/j.jdmm.2020.100552

12. Marlet, Gerard and Clemens van Woerkens, 'The Dutch Creative Class and How it Fosters Urban Employment Growth'. Urban Studies 44, no 13 (2007), 26052626. Online: https://doi.org/10.1080/00420980701558434

13. Mellander, Charlotta and Richard Florida, 'The Creative Class or Human Capital? Explaining Regional Development in Sweden'. Working Paper Series in Economics and Institutions of Innovation, 2007. Online: www.researchgate.net/publication/5094399_The_ Creative_Class_or_Human_Capital_Explaining_Regional_Development_in_Sweden 
14. Mellander, Charlotta and Richard Florida, 'The Rise of Skills: Human Capital, the Creative Class, and Regional Development', in Handbook of Regional Science, ed. by Manfred M Fischer and Peter Nijkamp. Berlin-Heidelberg: Springer, 2019. Online: https://doi.org/10.1007/978-3-642-36203-3_18-1

15. Möller, Joachim and Annie Tubadji, 'The Creative Class, Bohemians and Local Labor Market Performance'. Jahrbücher für Nationalökonomie und Statistik 229, no 2-3 (2009). Online: https://doi.org/10.1515/jbnst-2009-2-312

16. MyHelsinki, 'Work life worth living'. MyHelsinki, 16 December 2020. Online: www. myhelsinki.fi/en/info/work-life-worth-living

17. National Association of City Transportation Officials, 'Streets for Pandemic: Response \& Recovery'. News Release, 25 June 2020. Online: https://nacto.org/wp-content/ uploads/2020/09/Streets_for_Pandemic_Response_Recovery_Full_20-09-24.pdf

18. Naylor, Ted D and Richard Florida, 'The Rise of the Creative Class: And How It's Transforming Work, Leisure, Community and Everyday Life'. Canadian Public Policy/ Analyse de Politiques 29, no 3 (2003), 378-379. Online: https://doi.org/10.2307/3552294

19. Timár, Judit, 'The main features of suburbanization in the Great Hungarian Plain'. Landscape and Urban Planning 22, no 2-4 (1992), 177-187. Online: https:/doi. org/10.1016/0169-2046(92)90021-Q

20. Toman, Julia, 'How does the stress level change in cities?' Online: https://34travel.me/ post/stressful-cities-ranking

21. Vinogradskaya, O Y, 'Why and from what townspeople move to the village: Phenomenology and practice'. Russian Peasant Studies 4, no 3 (2019), 140-155. Online: https://doi.org/10.22394/2500-1809-2019-4-3-140-155

22. VMware, 'What is Remote-first?', s. a. Online: www.vmware.com/topics/glossary/ content/remote-first

23. Williams, Allan M, Russell King, Anthony Warnes and Guy Patterson, 'Tourism and international retirement migration: New forms of an old relationship in southern Europe'. Tourism Geographies 2, no 1 (2000), 28-49. Online: https://doi. org/10.1080/146166800363439

24. Wise, Hannah, 'How to Move During the Coronavirus'. The New York Times, 24 July 2020. Online: www.nytimes.com/2020/07/24/style/moving-during-covid-coronavirus. html

Anastasiia Yezhova is a PhD student of the Doctoral School of Public Administration Sciences at the University of Public Service (UPS). Having been awarded a scholarship by the "Stipendium Hungaricum" programme, she received her Master's Degree at UPS in 2018 at the Faculty of International and European Studies. She continued her academic career there and in the same year, she started a $\mathrm{PhD}$ programme, writing her dissertation on the topic of "Strategic City Marketing in Ukrainian Local Government: Case Study of Sumy City" (field of Public Management and Sociology) under the supervision of Prof. Norbert Kis, PhD and Bajnai László, PhD. 